\title{
First Record of a Novel Mitochondrial DNA Haplotype of marmoratus Lineage of Salmo trutta in Turkey
}

\author{
Fevzi Bardakci ${ }^{1,2, *}$ (D) Nazan Acar ${ }^{1}$, Tulin Arslan ${ }^{3}$, Riadh Badraoui ${ }^{2}$ \\ ${ }^{1}$ Adnan Menderes University, Faculty of Arts and Sciences, Department of Biology, Aydin, Turkey. \\ ${ }^{2}$ University of Ha'il, College of Science, Department of Biology, Ha'il, KSA. \\ ${ }^{3}$ Muğla Sıtkı Kocman University, Faculty of Fisheries, Department of Aquaculture, 48170 Mentese, Mugla, Turkey.
}

\section{How to cite}

Bardakci, F., Acar, N., Arslan, T., Badraoui, R. (2022). First Record of a Novel Mitochondrial DNA Haplotype of marmoratus Lineage of Salmo trutta in Turkey. Genetics of Aquatic Organisms, 6(1), GA452. http://doi.org/10.4194/GA452

\section{Article History}

Received 20 April 2021

Accepted 25 August 2021

First Online 26 August 2021

\section{Corresponding Author}

Tel.: +905334481991

E-mail: fevzi.bardakci@gmail.com

\author{
Keywords \\ Salmo trutta \\ marmoratus \\ Phylogenetics \\ Phylogeography \\ Mitochondrial DNA
}

\begin{abstract}
A new record of a marble trout mtDNA haplotype known to be restricted to Adriatic basin (called marmoratus (MA) lineage within Salmo trutta complex) has been reported from Eşen Stream in the Aegean Sea basin of southwestern Turkey, based on sequence data of the mitochondrial DNA control region. The results of this study showed a single unique haplotype from this population, called MATR1. Phylogenetic analyses of this haplotype along with other haplotypes belonging to different mitochondrial DNA lineages of the $S$. trutta complex confirmed the existence of the marmoratus lineage in Turkey, suggesting a possible river capture between the Adriatic and Aegean Sea basins until the last (Würmian) marine regression.
\end{abstract}

\section{Introduction}

The brown trout (Salmo trutta Linnaeus, 1758) is the most widely distributed species native to Eurasia and North Africa. The species displays a considerable amount of morphological variation and plasticity in many aspects of its morphology, ecology and behaviour. Based on the sequence divergence in the two segments of the mtDNA control region, five major evolutionary lineages were proposed: Danubian (DA), Atlantic (AT), Mediterranean (ME), Adriatic (AD) and marmoratus (MA) (Bernatchez, 2001). In addition, a highly divergent lineage called Tigris (TI) (Bardakci et al., 2006) from Turkey has been described (Susnik et al., 2005). Moreover, Vera et al. (2010) have also reported another lineage confined to the Duero River in the Iberian Peninsula.

Turkey is one of the most important geographical regions with high biodiversity and endemism due to its overlapping location with at least three biodiversity hotspot regions, Caucasus (northeastern Turkey), IranoAnatolian (central and eastern Turkey) and Mediterranean basin (southern Turkey) (Conservation International, 2005; Mittermeier et al., 2005). One of the most recent studies on freshwater fish diversity reported that 194 (47.4\%) species of Turkish freshwater ichthyofauna are endemic, and 12 of them belong to the Salmonidae family (Çiçek et al., 2018).

Considerable variation in the external morphology of brown trout across Turkey were reported in early 
studies, leading to many taxonomic units (reviewed by Geldiay and Balik, 2007; Turan et al., 2009; Turan et al. 2011;2012), though hybridization between different morph of the DA lineage in Turkey proposed a single taxonomic unit, Salmo trutta (Kalayci et al., 2018). Molecular studies on brown trout in Turkey have also revealed that there is a large amount of genetic variation and genetic structuring in brown trout populations (Bernatchez, 2001; Bardakci et al., 2006; Arslan and Bardakci, 2010; Ozen, 2013). Previous mtDNA analyses based on PCR-RFLP of mtDNA NADH $5 / 6$, cytochrome $b$ and control region showed that all Turkish brown trout populations were clustered into three distinct lineages, DA, AD and TI (Bardakci et al., 2006). While the $A D$ lineage is widespread in the Mediterranean and Adriatic basin, the DA lineage is predominantly seen in the Black/Caspian/Aral seas basins. TI lineage has only reported from a tributary of the Tigris River (Catak Stream) in the Persian Gulf basin.

Molecular phylogenetic analyses of brown trout based on analyses of mtDNA sequences showed that native range of a distinct marmoratus lineage within $S$. trutta complex was confined mainly to the Adriatic Sea basin, northern Italy, Slovenia, Croatia, Albania and Greece (Bernatchez, 2001; Apostolidis et al., 1997). Moreover, extensive introgression has been reported between native marble trout ( $S$. marmoratus) and brown trout (S. trutta) within the western Po basin (Giuffra et al., 1996), Slovenia (Fumagalli et al., 2002) and northern Italy (Meraner et al., 2007).

In this study, the complete sequences of the mtDNA control region obtained from the S. trutta population in Eşen Stream in Turkey were analysed together with previously reported brown trout mtDNA haplotypes to determine the evolutionary relationships of this population within the S. trutta complex. Findings from this study might shed light on our understanding of the impact of major historical events on the distribution of species.

\section{Materials and Methods}

\section{Sampling and DNA isolation}

We have analyzed six specimens from Eşen Stream in the Aegean Sea basin of southwestern Turkey (Figure 1). Brown trout specimens were caught by electrofishing and preserved in $95 \%(\mathrm{v} / \mathrm{v})$ ethanol. Total genomic DNA from muscle tissue at the bottom of dorsal fin of specimens was isolated following the method described in Bardakci \& Skibinski (1994) with a modification useing two steps of phenol-chloroform (25 phenols: 24 chloroform: 1 isoamyl alcohol) before. Precipitated DNA was re-suspended in distilled water and quantified with a spectrophotometer (Nanodrop1000; NanoDrop Technologies, Wilmington, DE, USA) at a wavelength of $260 \mathrm{~nm}$.

\section{DNA amplification and sequencing}

Approximately $1012 \mathrm{bp}$ of the mtDNA control region were amplified using primers, PST (5'CCAAAGCTAAAATTCTAAAT-3') and FST (5'GCTTTAGTTAAGCTACGC-3') (Cortey et al., 2004). The temperature profile for the 30 cycles of amplification reaction was as follows: initial denaturation at $94^{\circ} \mathrm{C}$ for $1 \mathrm{~min}$, denaturation at $94^{\circ} \mathrm{C}$ for $30 \mathrm{~s}$, annealing at $52^{\circ} \mathrm{C}$ for $1 \mathrm{~min}$, extension at $72^{\circ} \mathrm{C}$ for $1 \mathrm{~min}$, repeated for 35 cycles and a final extension step at $72^{\circ} \mathrm{C}$ for $1 \mathrm{~min}$. To monitor the quality of the products, two microliters of each purified product were examined after electrophoresis in 1\% agarose gel. PCR products were visualized in agarose gel stained with ethidium bromide and visualized under UV light and purified with the GenElute PCR Clean-Up Kit ${ }^{\circledR}$ (Sigma-Aldrich, Germany). Purified PCR products were sequenced by Macrogen Europe B.V. (Amsterdam, Netherlands) using the BigDye Terminator Cycle Sequencing Kit (Applied Biosystems, Foster City, CA, USA) and an ABI 3730XL capillary sequencer.

\section{Sequence alignment and phylogenetic analysis}

A BLAST search was performed at NCBI to determine sequence homology of the mtDNA control region of trout samples from Eşen Stream named MATR1 (GenBank Accession no. JN543996.1) with those previously deposited in the GenBank. The results of this search showed the highest homology with sequences of the mtDNA control region of marmoratus strain followed by other strains of S. trutta, proving MATR1 is a new mtDNA haplotype, first identified in this study.

These sequences showing the highest homology with sequences of the mtDNA control region of different S. trutta strains deposited in the GenBank, and the sequences of S. salar mtDNA control region as an outgroup, were combined and aligned with MATR1 sequences to assess its phylogenetic position within the S. trutta complex. As a result, the $990 \mathrm{bp}$ of mtDNA Dloop region was successfully aligned using the Clustal W software (Thompson et al., 1994) in BioEdit version 7.1.3.0 (Hall, 1999).

The Neighbor-Joining method (Saitou and Nei, 1987) was used to construct a phylogenetic tree in MEGA X (Kumar et al., 2018). The evolutionary distances were computed using the Kimura 2-parameter method (Kimura, 1980), which was the best-fit model to our data, as inferred from MEGA $X$ software, following pairwise-deletion model with 1000 bootstrap replicates. Estimates of sequence divergences (Kimura 2-parameter distances) were also performed in MEGA X software.

\section{Results}

Sequencing of mtDNA control region has revealed a single haplotype, designated MATR1 (Accession no: 
JN543996) from six individuals from the Eşen Stream. A BLAST search was performed to determine the homology of this haplotype with the sequences from GenBank, and results showed that MATR1 is a unique distinct haplotype with close similarity to other known haplotypes of mtDNA control region of marmoratus lineage within $S$. trutta complex. The nucleotide differences between these sequences are given in Table 1. Estimated nucleotide sequence divergence values between these sequences showed that the pairwise sequence divergence of MATR1 haplotype with those known haplotypes of marmoratus lineage ranged from $0.205 \%$ to $0.411 \%$.

Furthermore, the sequences of 27 haplotypes of mtDNA control region of known mtDNA lineages of brown trout (Bernatchez, 2001; Weiss et al., 2001; Duftner et al., 2003; Cortey et al., 2004; Pujolar et al., 2011) were retrieved from the GenBank database and analyzed together with MATR1 haplotype to confirm phylogenetic position of this new haplotype within $S$. trutta complex. Phylogenetic analyzes distinguished five S. trutta lineages proposed by Bernatchez (2001), and TI lineage by Bardakci et al. (2006). NJ tree (Figure 2) confirmed phylogenetic position of MATR1 haplotype as a marmoratus lineage. The sequence divergence of this haplotype with other haplotypes of trout lineages ranged from $0.205 \%$ to $1.198 \%$. Overall results showed that a single unique haplotye identified from Eşen population clustered with the marmoratus haplotypes with a high bootstrap value (Figure 2), suggesting the presence of a marmoratus lineage within $S$. trutta complex in Turkey. In addition, Eşen population does not have a typical marble trout (S. marmoratus) color pattern as reported in previous studies (Pustovrh et al., 2011; Delling et al., 2020) but has some distinct phenotypic characteristics such as black spots with no white circles around on the most upper part of flanks and red ones on both upper, middle and lower part of flanks also with no white circles around, and a greater eye diameter (Figure 3).

Table 1. Variable nucleotide sites of MATR1 haplotype and other marmoratus haplotypes deposited in the GenBank.

\begin{tabular}{|c|c|c|c|c|c|c|c|c|}
\hline \multicolumn{9}{|c|}{ Variable sites } \\
\hline & $\stackrel{0}{\circ}$ & 芯 & $\stackrel{\stackrel{n}{n}}{\sim}$ & 운 & นก & $\stackrel{\stackrel{\sim}{N}}{N}$ & $\begin{array}{l}\infty \\
\infty \\
\sim\end{array}$ & นูก \\
\hline \multicolumn{9}{|c|}{ Haplotype } \\
\hline Ma2a & A & A & $T$ & C & - & $T$ & C & $\mathrm{T}$ \\
\hline Ma2b & A & A & $\mathrm{T}$ & C & - & C & C & $\mathrm{T}$ \\
\hline Ma1a & A & A & C & C & - & C & C & $\mathrm{T}$ \\
\hline MAcs4 & A & G & C & C & $\mathrm{T}$ & $\mathrm{C}$ & $\mathrm{C}$ & $\mathrm{T}$ \\
\hline MATR1 & A & A & $\mathrm{T}$ & C & - & C & $\mathrm{T}$ & C \\
\hline MAcs5 & G & A & $\mathrm{T}$ & C & $\mathrm{T}$ & C & C & $\mathrm{T}$ \\
\hline MAcs1 & A & A & C & C & - & C & C & $\mathrm{T}$ \\
\hline MaK1 & A & A & C & $\mathrm{T}$ & - & C & $\mathrm{T}$ & C \\
\hline
\end{tabular}

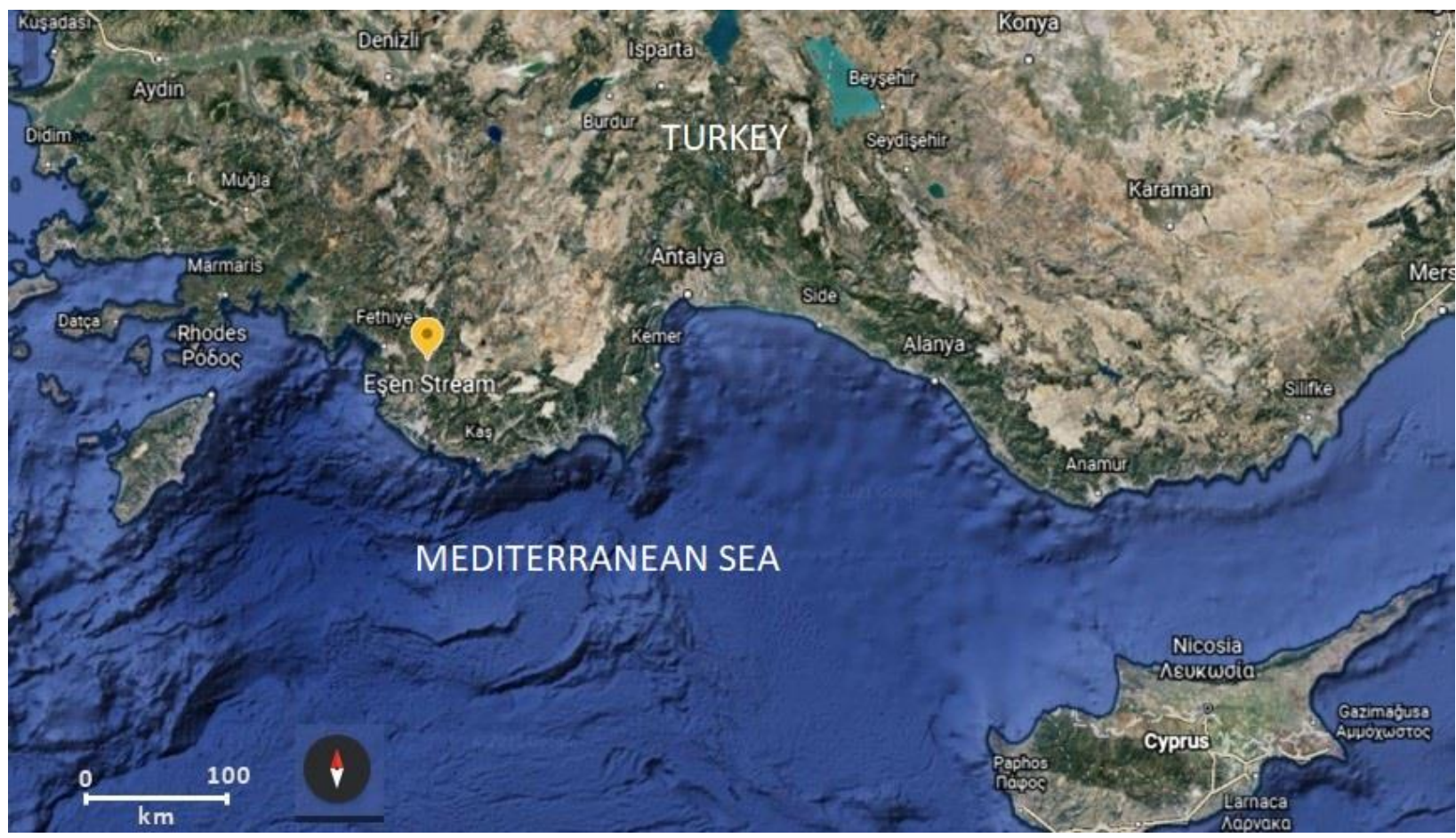

Figure 1. Sampling locality of marmoratus strain of S. trutta from the Eşen Stream (Coordinate: 36 59'49.2"N 29³6'26.6"E) 


\section{Discussion}

Extensive hybridization between brown trout and marble trout (S. marmoratus) has been reported in Slovenia and Italy (Fumagalli et al., 2002; Splendiani et al., 2006; Meraner et al., 2007). To our knowledge, there is no existence, stocking or promotion of the marmoratus lineage of $S$. trutta and marble trout in Turkey. The genotypes found in populations throughout the Mediterranean basin, from Spain to Turkey belong to one of the three major phylogenetic groups, $A D, M E$, MA. A dissertation on the population genetics and phylogenetics of brown trout in Turkey, based on the sequence data of mtDNA control region, has put forward the presence DA, AD, TI as well as MA mtDNA lineages (Ozen, 2013). The tree presented here suggest that the ME and AT lineages do not exist in Turkey. Splendiani et al. (2006) noted that the presence of

Table 2. Estimates of nucleotide divergence between sequences of marmoratus haplotypes using the Kimura 2-parameter model.

\begin{tabular}{|c|c|c|c|c|c|c|c|}
\hline Haplotypes & Ma2a & Ma2b & Ma1a & MAcs5 & MATR1 & MAcs5 & MAcs1 \\
\hline \multicolumn{8}{|l|}{ Ma2a } \\
\hline $\mathrm{Ma} 2 \mathrm{~b}$ & 0.00102 & & & & & & \\
\hline Ma1a & 0.00205 & 0.00102 & & & & & \\
\hline MAcs4 & 0.00308 & 0.00205 & 0.00102 & & & & \\
\hline MATR1 & 0.00308 & 0.00205 & 0.00308 & 0.00411 & & & \\
\hline MAcs5 & 0.00205 & 0.00102 & 0.00205 & 0.00308 & 0.00308 & & \\
\hline MAcs1 & 0.00205 & 0.00102 & 0.00000 & 0.00102 & 0.00308 & 0.00205 & \\
\hline MaK1 & 0.00514 & 0.00411 & 0.00308 & 0.00411 & 0.00205 & 0.00515 & 0.00308 \\
\hline
\end{tabular}

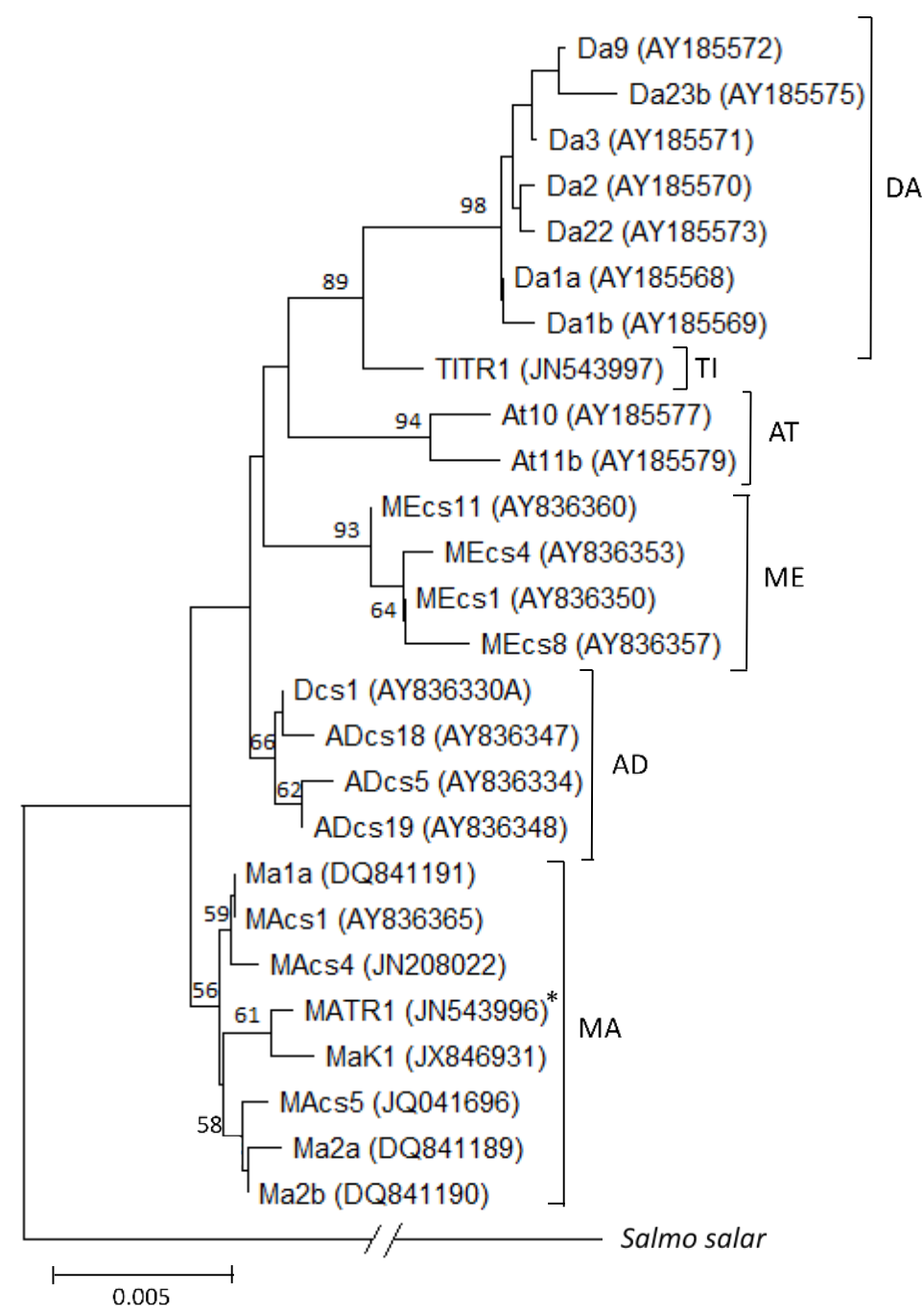

Figure 2. Neighbor-Joining tree of new MATR1 identified in this study (marked with an asterisk) and other mtDNA haplotypes of Salmo trutta linages based on mtDNA control region. Bootstrap values (1000 replicates) (>50\%) are shown above branches. Accession numbers of sequences are given in brackets. (AD, Adriatic; ME, Mediterranean; AT, Atlantic; MA, marmoratus, TI, Tigris and DA, Danubian). 


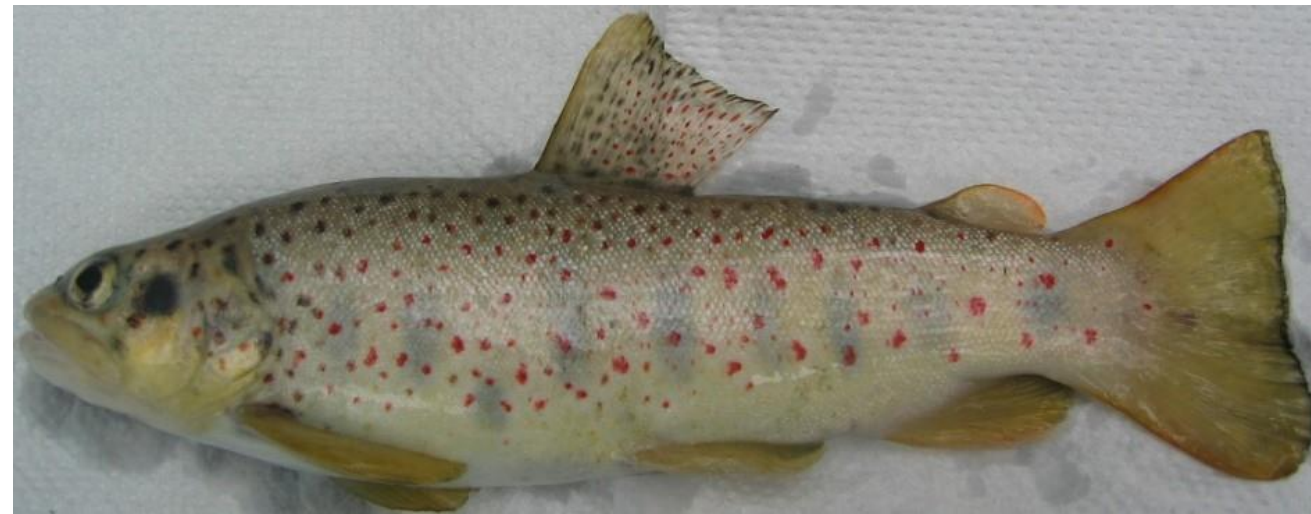

Figure 3. Photograph of a Salmo trutta individual from the Eşen Stream (Courtesy of Dr Yilmaz Ciftci).

marmoratus lineage in central Italy and in Greece might represent a remnant of an ancient, southernmost distribution as hypothesized by Antunes et al. (2002) based on analysis of transferrin gene. The net nucleotide divergence between MATR1 and other marmoratus haplotypes ranged from $0.205 \%$ to $0.411 \%$ (Table 2 ). Applying a mutation rate of $1-2 \%$ per million years, the time of diversification for this lineage would coincide with the Holocene (Bernatchez, 2001). Historical geography of Anatolia shows that there was a connection between the Southwestern Anatolian mainland and Greece (Perissoratis et al., 2018). In the late Pleistocene, sea level around the Mediterranean, including Adriatic and Aegean, was regularly lower than the current levels (approx. 100-130 m), resulting in the formation of land bridges. Approximately 21,500 years ago, there were extensive shelf areas in the northern Aegean Sea and in parts of the Ionian and the eastern Aegean seas. Land protrusions on either side of the Aegean Sea, separated locally by sea channels, formed a kind of land bridge connecting Asia Minor and Greece. At 11,800 years before present, the shelf was considerably diminished due to the last (Würmian) marine regression. Approximately 7,000-8,000 years ago, the sea gradually intruded the lowlands and costal configuration much like today's was formed (Perissoratis et al., 2018). Bianco (1995) suggested that the current distribution of endemic freshwater fishes in ichthyogeographic regions of western Europe (from Tuscano Latium to Aegeo-Macedo-Anatolian) was affected by river isolation that occurred during the last marine regression (about 15,000-18,000 years ago). Marine regression, which caused the rivers to diverge in the Late Pleistocene, played an important role in the diversification of fish species such as chub (Squalius cephalus) (Durand et al., 1999), and those reviewed in Bianco (1995).

In conclusion, these findings suggest that ancient river capture represents a strong vicariant event that might succeed a pattern of past fragmentation and genetic divergence of brown trout in the Mediterranean basin. It also supports the hypothesis of Antunes et al. (2002) suggested that the origin of MA lineage might be south of the current occurrence based on the genealogy of the transferring gene. This population deserves conservation, and further analysis of both mtDNA and nuclear DNA sequences from various parts of Anatolia would be useful to infer the phylogeographic relationships among the $S$. trutta complex as the area is considered a hotspot for biodiversity (Bardakci et al., 2006).

\section{Ethical Statement}

All listed co-authors declare that the present study was conducted in an ethical, professional and responsible manner.

\section{Funding Information}

There is no financial support for this project.

\section{Author Contribution}

F.B. conceived of the presented idea, supervised the findings, analyzed the data and wrote the manuscript. N.A. performed the experiments. T.A. provided fish tissue samples and reviewed the manuscript. R.B. conceptualization, provided critical comments and final approval of the manuscript

\section{Conflict of Interest}

The authors declare that they have no conflict of interest.

\section{References}

Antunes, A., Templeton, A.R., Guyomard, R., \& Alexandrino, P. (2002). The role of nuclear genes in intraspecific evolutionary inference: Genealogy of the transferrin Gene in the Brown Trout. Molecular Biology and Evolution, 19(8), 1272-1287.

https://doi.org/10.1093/oxfordjournals.molbev.a004188

Apostolidis, A.P., Triantaphyllidis, C., Kouvatsi, A., \& Economidis, P.S. (1997). Mitochondrial DNA sequence variation and phylogeography among Salmo trutta L. 
(Greek brown trout) populations. Molecular Ecology 6(6), 531-542. https://doi.org/10.1046/j.1365-294x.1997.d01-176.x

Arslan, S., \& Bardakci, F. (2010). Genetic structure of brown trout (salmo trutta) populations from Turkey based on microsatellite data. Biochemical Genetics, 48(11-12), 995-1014. https://doi.org/10.1007/s10528-010-9388-2f

Bardakci, F. \& Skibinski, D. (1994). Application of the RAPD technique in tilapia fish: species and subspecies identification. Heredity, 73, 117-123 (1994). https://doi.org/10.1038/hdy.1994.110

Bardakci, F., Degerli, N., Ozdemir, O., \& Basibuyuk, H.H. (2006). Phylogeography of the Turkish brown trout Salmo trutta L.: mitochondrial DNA PCR-RFLP variation. Journal of Fish Biology, 68(A), 36-55. https://doi.org/10.1111/j.00221112.2006.00948.x

Bernatchez, L. (2001). The evolutionary history of Brown trout (Salmo trutta L.) inferred from phylogeographic, nested clade, and mismatch analyses of mitochondrial DNA variation. Evolution, 55(2), 351-379. https://doi.org/10.1111/j.0014-3820.2001.tb01300.x

Bianco, P.G. (1995). Factors affecting the distribution of freshwater fishes especially in Italy. Cybium, 19, 241259.

Conservation International, 2005. Map of Biodiversity Hotspots.

http://www.conservation.org/Documents/cihotspotma p.pdf (accessed 13.02.11).

Cortey, M., Pla, C., \& García-Marín, J.-L. (2004). Historical biogeography of Mediterranean trout. Molecular Phylogenetics and Evolution, 33(3), 831-844. https://doi.org/10.1016/j.ympev.2004.08.012

Çiçek, E., Fricke, R., Sungur, S., \& Eagderi, S. (2018). Endemic freshwater fishes of Turkey. FishTaxa, 3(4), 1-39.

Delling, B.,, Sabatini A., Muracciole, S., Tougard, C. \& Berrebi P. (2020). Morphologic and genetic characterization of Corsican and Sardinian trout with comments on Salmo taxonomy. Knowledge and Management of Aquatic Ecosystems, 421: 21. https://doi.org/10.1051/kmae/2020013

Duftner, N., Weiss, S., Medgyesy, N., \& Sturmbauer, C. (2003). Enhanced phylogeographic information about Austrian brown trout populations derived from complete mitochondrial control region sequences. Journal of Fish Biology, 62(2), 427-435. https://doi.org/10.1046/j.1095-8649.2003.00038.x

Durand, J.D., Templeton, A.R., Guinand, B., Imsiridou, A., \& Bouvet, Y. (1999). Nested clade and phylogeographic analyses of the chub, leuciscus cephalus (Teleostei, cyprinidae), in Greece: Implications for Balkan peninsula biogeography. Molecular Phylogenetics and Evolution, 13(3), 566-580. https://doi.org/10.1006/mpev.1999.0671

Fumagalli, L., Snoj, A., Jesenšek, D., Balloux, F., Jug, T., Duron, O., Brossier, F., Crivelli, A.J., \& Berrebi, P. (2002). Extreme genetic differentiation among the remnant populations of marble trout (Salmo marmoratus) in Slovenia. Molecular Ecology, 11(12), 2711-2716. https://doi.org/10.1046/j.1365-294x.2002.01648.x

Geldiay, R. \& Balık. S. (2007). Türkiye Tatısu Balıkları (in Turkish). Izmir, Turkey, Ege Üniversitesi Su Ürünleri Fakültesi Yayınları, 46, (5. Baskı), Ege Üniversitesi Basımevi, İzmir, 644 pp.

Giuffra, E., Guyomard, R., \& Forneris, G. (1996). Phylogenetic relationships and introgression patterns between incipient parapatric species of Italian brown trout (Salmo trutta L. complex). Molecular Ecology, 5(2), 207-220. https://doi.org/10.1111/j.1365-294x.1996.tb00308.x

Hall TA (1999). Bioedit: a user friendly biological sequence aligment editor and analysis program for Windows 95/98/NT. Nucleic Acids Symposium Series 41: 95-98.

Kalayci. G., Ozturk, R.C., Capkin, E. \& Altinok, I. (2018). Genetic and molecular evidence that brown trout Salmo trutta belonging to the Danubian lineage are a single biological species. Journal of Fish Biology, 93, 792-804. https://doi. org/10.1111/jfb.13777.

Kimura, M. (1980). A simple method for estimating evolutionary rates of base substitutions through comparative studies of nucleotide sequences. Journal of Molecular Evolution, 16(2), 111-120. https://doi.org/10.1007/bf01731581

Kumar, S., Stecher, G., Li, M., Knyaz, C., \& Tamura, K. (2018). MEGAX: Molecular evolutionary genetics analysis across computing platforms. Molecular Biology and Evolution, 35(6), 1547-1549. https://doi.org/10.1093/molbev/msy096

Meraner, A., Baric, S., Pelster, B., \& Dalla Via, J. (2007). Trout (Salmo trutta) mitochondrial DNA polymorphism in the centre of the marble trout distribution area. Hydrobiologia, 579(1), 337-349. https://doi.org/10.1007/s10750-006-0479-3

Mittermeier, R.A., Gil, P.R., Hoffman, M., Pilgrim, J., Brooks, T., Mittermeier, J.C., ... da Fonseca, G.A.B. (2005). Hotspots Revisited: Earth's Biologically Richest and Most Endangered Terrestrial Ecoregions. Amsterdam, Netherlands, Amsterdam University Press., 392 pp

Ozen N (2013). Molecular phylogeny of brown trouts (Salmo trutta L.) in Turkey. PhD Thesis. Adnan Menderes University, Aydin, Turkey.

Perissoratis, K., Conispoliatis, N., Zimianitis, E., Galanopoulou, S., \& Zaharak, P. (2018). Marine geological researches in the greater bay of Navarino area, Southern Ionian sea. Bulletin of the Geological Society of Greece, 34(2), 655. https://doi.org/10.12681/bgsg.17125

Pujolar, J.M., Lucarda, A.N., Simonato, M., \& Patarnello, T. (2011). Restricted gene flow at the micro- and macrogeographical scale in marble trout based on mtDNA and microsatellite polymorphism. Frontiers in Zoology, 8(1), 7. https://doi.org/10.1186/1742-9994-8-7

Pustovrh, G., Sušnik Bajec, S., \& Snoj, A. (2011). Evolutionary relationship between marble trout of the northern and the southern Adriatic basin. Molecular Phylogenetics and Evolution, 59(3), 761-766. https://doi.org/10.1016/j.ympev.2011.03.024

Saitou, N \& Nei, M. (1987). The neighbor-joining method: a new method for reconstructing phylogenetic trees. Molecular Biology and Evolution, 4(4), 406425. https://doi.org/10.1093/oxfordjournals.molbev.a0 40454

Splendiani, A., Giovannotti, M., Cerioni, P.N., Caniglia, M.L., \& Caputo, V. (2006). Phylogeographic inferences on the native brown trout mtDNA variation in central Italy. Italian Journal of Zoology, 73(2), 179-189. https://doi.org/10.1080/11250000600679751

Susnik, S., Schoffmann, J., \& Weiss, S. (2005). Genetic verification of native brown trout from the Persian Gulf (Catak Cay River, Tigris basin). Journal of Fish Biology, 67(3), 879-884. https://doi.org/10.1111/j.00221112.2005.00780.x

Thompson, J.D., Higgins, D.G., \& Gibson, T.J. (1994). CLUSTAL 
W: improving the sensitivity of progressive multiple sequence alignment through sequence weighting, position-specific gap penalties and weight matrix choice. Nucleic Acids Research, 22(22), 4673-4680. https://doi.org/10.1093/nar/22.22.4673

Turan, D., Kottelat, M., Engin, S. (2009). Two new species of trouts, resident and migratory, sympatric in streams of northern Anatolia (Salmoniformes: Salmonidae). Ichthyological Exploration of Freshwaters 20, 333-364.

Turan, D., Kottelat, M. \& Bektaş, Y. (2011). Salmo tigridis, a new species of trout from the Tigris River, Turkey (Teleostei: Salmonidae) Zootaxa, 2993(1), 23-33. https://doi.org/10.11646/zootaxa.2993.1.2

Turan, D., Kottelat, M. Engin, S. (2012). The trouts of the Mediterranean drainages of southern Anatolia, Turkey, with description of three new species (Teleostei: Salmonidae). Ichthyological Exploration of Freshwaters, 23, 219-236.

Vera, M., Cortey, M., Sanz, N., \& García-Marín, J.-L. (2010). Maintenance of an endemic lineage of brown trout (Salmo trutta) within the Duero river basin. Journal of Zoological Systematics and Evolutionary Research, 48(2), 181-187. https://doi.org/10.1111/j.14390469.2009.00547.x

Weiss, S., Schlotterer, C., Waidbacher, H., \& Jungwirth, M. (2001). Haplotype (mtDNA) diversity of brown trout Salmo trutta in tributaries of the Austrian Danube: massive introgression of Atlantic basin fish - by man or nature? Molecular Ecology, 10(5), 1241-1246. https://doi.org/10.1046/j.1365-294x.2001.01261.x 